\title{
POTRET PEREMPUAN PARANGTRITIS DALAM FILM SITI
}

\author{
Efri Khoirunnisa Hartoyo dan Sumekar Tanjung \\ Universitas Islam Indonesia \\ efrikhoirunnisahartoyo@students.uii.ac.id; sumekar.tanjung@uii.ac.id
}

\begin{abstract}
This study aims to explain the representation of Parangtritis women in the Siti movie. Coastal women plays an important role in economic activities on the land. The system of division of labor in coastal communities requires women to be involved in the public sphere. Through the semiotic method of Roland Barthes, this research reveals the representation of coastal women through the four shots shown. There are three findings in this study. First, coastal women are inseparable from the devotion to the husband and family. Second, helping their husband's income in the public space. Third, self helplessness which resulted in limited area of work in public space. These three findings are not a research effort to generalize the portraits of coastal women. With the dual roles, eventually coastal women cannot escape from their domestic responsibilities due to economic distress.
\end{abstract}

Keywords: Movie, women, coastal women, Javanese, gender.

\begin{abstract}
ABSTRAK
Penelitian ini bertujuan untuk menjelaskan representasi perempuan Parangtritis pada film Siti. Perempuan pesisir memegang peran penting dalam kegiatan ekonomi di darat. Sistem pembagian kerja pada masyarakat pesisir mengharuskan perempuan terlibat dalam ruang publik. Melalui metode semiotika Roland Barthes, penelitian ini mengungkap representasi perempuan pesisir melalui empat shot yang ditampilkan. Terdapat tiga temuan pada penelitian ini. Pertama, mobilitasnya pada ruang domestik. Perempuan pesisir tidak terlepas dari pengabdiannya kepada suami dan keluarga. Kedua, membantu penghasilan suami di ruang publik. Ketiga, ketidakberdayaan diri yang mengakibatkan terbatasnya perolehan pekerjaan di ruang publik. Ketiga temuan ini bukanlah suatu usaha peneliti untuk melakukan generalisasi terhadap potret perempuan pesisir. Dengan peran ganda yang dimiliki perempuan pesisir akibat desakan ekonomi, pada akhirnya perempuan pesisir tidak dapat melepaskan diri dari tanggung jawab di wilayah domestiknya.
\end{abstract}

Kata-kata Kunci: Film, perempuan, pesisir, Jawa, gender. 


\section{PENDAHULUAN}

Penelitian ini bertujuan untuk menjelaskan bagaimana film Siti merepresentasikan perempuan pesisir pada setiap tanda yang disajikan. Penelitian ini berusaha melengkapi hasil penelitian sebelumnya milik Prasetyo (2017). Hadirnya penelitian ini diharapkan mampu melengkapi khasanah kajian akademik dalam ranah ilmu komunikasi dan media.

Dalam kebanyakan film di Indonesia, perempuan menjadi objek perhatian. Kebebasan media menempatkan kaum perempuan sebagai objek dalam berbagai kesempatan dan alasan. Representasi perempuan dalam film menjadi penting mengingat film merupakan media komunikasi yang dapat mengubah pandangan seseorang.

Film Siti dipilih karena dirasa mampu merepresentasikan sosok perempuan nelayan dengan segala risiko. Melalui konsep hitam putih, Siti menyajikan kehidupan perempuan yang terbatas. Film yang berlatar Parangtritis ini seolah membenarkan gagasan Kusnadi (2006) bahwa perempuan pesisir memegang peran penting dalam kegiatan sosial ekonomi di darat. Sementara lakilaki berperan di area laut untuk mencari nafkah dan mencari ikan. Dampak dari sistem pembagian kerja berdasarkan gender ini mengharuskan perempuan pesisir terlibat dalam peran publik, yaitu turut mencari tambahan nafkah bagi keluarga yang disebabkan penghasilan nelayan yang tidak tentu.

\section{KERANGKA PEMIKIRAN}

Film digunakan sebagai media yang mencerminkan realitas, bahkan membentuk realitas. Cerita yang ditayangkan melalui film dapat berbentuk fiksi atau non fiksi. Film banyak digunakan untuk menyampaikan pendapat dan informasi para pembuat film kepada masyarakat. Elvinaro (2004) mendefiniskan bahwa film adalah kompleksitas pertanda sosial, psikologi, dan estetika.

Film menyimpan dua komponen pembentuk, yakni naratif dan sinematik. Komponen naratif mewujudkan substansi film yang diolah seperti konflik, tokoh, dan lainnya. Sedangkan komponen sinematik mewujudkan substansi teknis seperti sinematografi, editing, framing, suara, dan lainnya (Kolker, 2001). Penerimaan pesan dalam film oleh sutradara kepada penonton terjadi melalui bahasa. Dengan berbedanya pengalaman berbahasa yang dimiliki penonton, maka berbeda pula penerimaannya bagi penonton. Bahasa disampaikan melalui wujudnya sebagai kata, gambar, ide, emosi, fakta, dan lainnya dalam berbagai 
tanda dan citra yang dipahami secara kultural. Inilah yang pada akhirnya disebut sebagai konsep representasi. Ini digunakan untuk menjelaskan ekspresi relasi antara teks film dengan realitas atau ideologi kebudayaan dimana film diproduksi.

Dalam karyanya, Prasetyo (2017) mengungkap mitos perempuan pesisir Jawa berdasarkan tiga temuan. Pertama, dilihat dari segi tempat tinggal dan pakaian, Siti direpresentasikan sebagai masyarakat kelas bawah. Kedua, perempuan masih dibebani dengan peran domestiknya untuk mengurus rumah tangga. Ketiga adalah rendahnya tingkat religiusitas perempuan pesisir Jawa.

Temuan tersebut seolah kembali mempertegas konsep kanca wingking yang juga dinarasikan oleh Sukri dan Sofwan (2001). Istilah kanca wingking untuk menyebut istri menunjukkan bagaimana status perempuan Jawa diposisikan dan dibandingkan dengan kaum laki-laki. Perempuan yang memiliki tugas domestik di dalam rumah yakni mencuci, memasak, dan melayani suami, menjadikan status perempuan lebih rendah daripada laki-laki yang selalu berada di ruang publik.

Penempatan posisi tersebut sudah dijelaskan oleh Siregar (2004) bahwa konstruksi sosial yang berasal dari kekuasaan patriarki mengakibatkan struktur sosial yang tidak adil dan bersifat tidak setara diantara mayoritas dan minoritas dalam konteks ras, anutan agama, nilai kultural dan kecenderungan seksual. Masalah mayoritas dan minoritas tidak sepenuhnya atas dasar populasi, tetapi posisi dalam konstruksi sosial menjadi tidak berdaya. Dalam konstruksi patriarki, laki-laki menempati peran di ruang publik, sedangkan perempuan ditempatkan dalam ruang privat.

Untuk mengetahui status sosial seorang perempuan pada masyarakat pesisir, maka dapat dilihat dari hubungan dan kedudukan suami istri dalam rumah tangga. Allport (dalam Salamah, 2005) menyatakan bahwa aspek terpenting dalam keluarga adalah posisi anggota keluarga dalam melaksanakan distribusi dan alokasi kekuasaan serta pembagian wilayah kerja dalam keluarga. Kekuasaan yang dimaksud adalah kemampuan untuk mengambil keputusan yang dapat mempengaruhi kehidupan keluarga. Keputusan tersebut bisa dibagi merata atau tidak di antara suami dan istri. Sedangkan pembagian kerja didasarkan pada pola peran yang ada pada keluarga.

Pada masyarakat nelayan tidak selalu ada pembagian kerja antara 
pria/suami dan wanita/istri dalam kehidupan rumah tangga. Ada masyarakat nelayan yang melakukan pembagian kerja dan ada yang tidak melakukannya berdasar keadaan fisik. Tujuannya agar mereka dapat mempertahankan kelangsungan hidup. Secara umum masyarakat nelayan melakukan pembagian kerja berdasar keadaan fisik. Dalam pembagian kerja yang tajam ini, suami menangkap ikan dan isteri mengolah ikan di rumah. Karena pekerjaan sebagai nelayan membutuhkan stamina yang kuat dan baik, wanita dianggap tidak mempunyai fisik yang kuat seperti pria. Kenyataan ini berbeda dengan masyarakat nelayan yang tidak mengenal pembagian kerja berdasar keadaan fisik, di mana tidak hanya pria saja yang menangkap ikan, wanita nelayan juga terlibat dalam operasi penangkapan ikan dan hidup di perahu (Salamah, 2005).

Menurut Kusnadi (2006), perempuan nelayan memiliki potensi besar dalam membangun wilayah pesisir. Profesi sebagai nelayan dipengaruhi oleh banyak aspek, seperti musim dan iklim di laut yang menentukan tangkapan. Ketidakstabilan menjadi seorang nelayan membuat para istri nelayan berlaku sebagai tiang penyangga kehidupan rumah tangga. Dengan demikian, perempuanlah yang berperan penting dalam menghadapi kemiskinan (Kusumo, 2013).

Secara umum pandangan laki-laki terhadap kaum perempuan yang bekerja di desa pesisir terbagi menjadi tiga kelompok. Pertama kelompok yang tidak setuju istrinya bekerja, karena sesuai dengan ajaran Islam tentang tanggung jawab utama suami adalah bekerja memenuhi kebutuhan keuarga. Jika istri bekerja kekhawatiran akan tugas domestiknya akan terbengkalai. Kedua, boleh bekerja tetapi cukup dikendalikan dari rumah dan tidak perlu jauh-jauh keluar rumah untuk bekerja. Ketiga, setuju kaum perempuan bekerja di sektor publik untuk memperoleh penghasilan dalam rangka memenuhi kebutuhan rumah tangga. Dorongan kerja ini semakin kuat karena penghasilan melaut tidak dapat dipastikan (Kusnadi, 2015).

\section{METODE PENELITIAN}

Peneliti menggunakan metode semiotika untuk mengulas setiap tanda pada film Siti. Dalam mengumpulkan data, peneliti melakukan pengamatan secara menyeluruh dan mendalam terhadap empat shoot pada film ini. Peneliti menyelesaikan penelitian melalui lima tahap. Pertama, peneliti mengelompokkan data berdasarkan unit analisis yang berkaitan dengan konstruksi perempuan. 
Lalu tahap kedua, menganalisis objek dengan mengartikan adegan-adegan yang telah dipilih. Tahap ketiga yaitu menafsirkan setiap simbol dan tanda yang terdapat pada adegan-adegan tersebut dan mengaitkan dengan teori yang ada. Pada tahap keempat, peneliti melakukan penelusuran pustaka dan dokumen sekunder lain untuk memperoleh kedalaman pembahasan. Terakhir, peneliti menarik kesimpulan atas temuan dari pertanyaan penelitian yang ditentukan.

Peneliti menelaah makna denotasi dan konotasi dari tanda pada film Siti melalui metode semiotika Roland Barthes. Sulit melakukan analisis menyeluruh terhadap suatu film tanpa mengevaluasi makna denotatif dan konotatif dari tanda yang ditunjukkan di dalamnya. Sebagai ilmu yang mempelajari tanda, semiotika dapat mengungkap bagaimana seseorang membuat tanda, membangun sistem dari tanda, dan berkomunikasi melalui tanda.

Semiotika muncul sebagai alternatif untuk melihat komunikasi sebagai suatu proses (Balci \& Ozgen, 2017). Dalam semiotika, denotasi dan konotasi adalah istilah yang menggambarkan hubungan antara penanda dan petanda. Denotasi cenderung dideskripsikan sebagai makna literal dan jelas secara akal sehat dari suatu tanda. Makna denotasi suatu tanda disetujui secara luas oleh anggota budaya yang sama. Konotasi digunakan untuk merujuk pada gabungan pemaknaan sosial budaya, ideologi dan emosional dari tanda (Chandler, 2007) yang kemudian melahirkan mitos. Diskursus gender adalah salah satu contoh kerangka budaya penjelas tentang mitos. Mitos budaya membantu untuk memahami pengalaman seseorang dalam budaya, baik mengekspresikan maupun mengatur suatu konseptualisasi dalam budaya (Lakoff \& Johnson dalam Chandler, 2007). Dalam kerangka kajian budaya Barthesian, mitos, seperti konotasi, dilihat sebagai tatanan makna yang lebih tinggi. Barthes tidak melihat mitos-mitos budaya kontemporer sebagai sekadar penggambaran konotasi yang berpola, tetapi sebagai narasi ideologis.

\section{HASIL DAN PEMBAHASAN}

\section{Mobilitas pada Ruang Domestik}

\section{a. Bakti pada Suami}

Level denotasi. Siti duduk dan menyuapi suaminya, Bagus, sambil bercerita tentang pendapatannya hari itu. Bagus hanya menatap Siti tanpa mengatakan apapun. Level konotasi. Melayani suami. Siti tidak melupakan tugasnya untuk melayani suami dengan menyuapi suaminya. Secara tidak langsung Bagus 
sebagai suami tidak bisa hanya mengabaikan Siti, walaupun sedang tidak dalam kondisi dan hubungan yang baik. Arah pandangan yang melihat ke arah wajah Siti menandakan bahwa walaupun sedang dalam kondisi yang buruk, Bagus tetap mendengarkan cerita Siti.

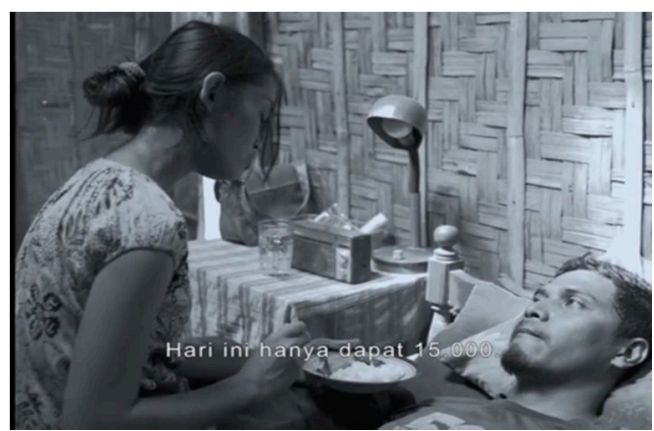

Gambar 1: Siti Menyuapi Bagus

(menit ke 00:36:32)

Melayani dan mengurus berbagai aspek dalam keluarga telah menjadi tanggung jawab penuh seorang perempuan sebagai seorang istri, tidak terkecuali pada perempuan pesisir. Membimbing dan mendidik anak, mendampingi dan membantu suami adalah peran seorang ibu demi keberhasilan dalam membentuk rumah tangga yang bahagia dan sejahtera.

Kegiatan melaut menghabiskan waktu yang tidak sebentar. Saat suami melaut, istri mengambil alih semua urusan keluarga baik pekerjaan domestiknya sendiri maupun kegiatan publik suaminya. Istri yang mengambil inisiatif untuk memerankan diri sebagai bagian dari peran yang selama ini dianggap tabu dalam masyarakat Jawa, yakni sektor publik. Realitas ini mengharuskan istri merambah untuk mengambil dua peran sekaligus, peran domestik sekaligus publik. Dalam konteks penelitian ini menunjukkan pembakuan peran antara mereka, laut menjadi wilayah kegiatan suami, sedangkan darat menjadi wilayah tanggung jawab istri (Dzulkarnain, 2009). Jam kerja dalam dua wilayah tidak bisa mengurangi tanggung jawabnya di wilayah domestik. Keseimbangan antara kedua wilayah kerja tersebut sebisa mungkin diseimbangkan oleh perempuan.

\section{b. Dapur sebagai Ruang Privat}

Level Denotasi. Siti duduk dalam ruangan yang terdapat banyak panci, kayu bakar, dan beralaskan tanah. Dalam kondisi ruangan yang didominasi peralatan memasak, ruangan ini biasa dikenal sebagai dapur. Dapur merupakan ruangan untuk mengolah dan mempersiapkan makanan.

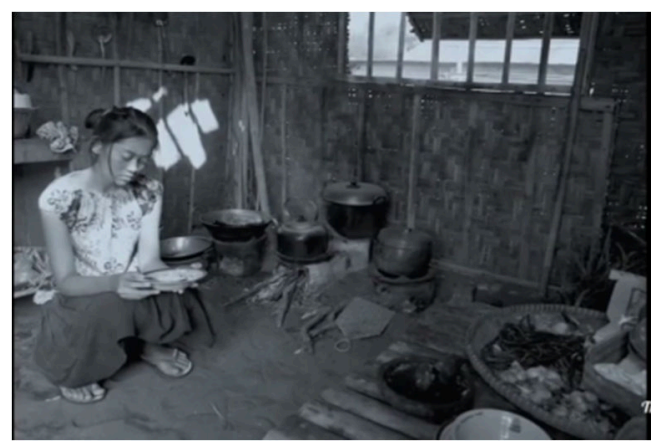

Gambar 2: Siti Makan di Dapur (menit ke 00:23:53) 
Level Konotasi. Ruang privat. Dapur dianggap sebagai ruang terbatas yang hanya boleh dimasuki oleh pemilik rumah. Diamnya Siti merupakan wujud represntasi komunikasi intrapersonal. Dari mimik wajah Siti, penonton dapat melihat ke dalam ruang privat berupa ratapan atas kondisi yang dialaminya. Dapur dikendalikan oleh Siti sebagai ruang untuk berkomunikasi secara pribadi yang kemudian menjadikannya sebagai kepanjangan dari dirinya. Apapun yang ia persiapkan untuk memasak, mempersiapkan makanan, bergantung pada kondisi yang sedang ia alami.

Ruang mobilisasi perempuan hanya pada ranah domestik. Dalam kebudayaan tradisional, dapur hanya boleh dimasuki oleh wanita dan tabu bagi kaum pria, namun tempatnya tetap di belakang rumah. Perempuan bertanggungjawab dalam urusan domestik karena karakter sosial yang telah terberikan. Sifat feminin pada perempuan dianggap lebih tepat dalam urusan domestik dibandingkan sifat maskulin pada laki-laki. Sejak proses mengandung, melahirkan, dan menyusui, cukup mengesahkan bahwa urusan domestik menjadi tanggung jawab perempuan. Sebagaimana dijelaskan Boserup dalam Boulding (2016) bahwa perempuan sebagai feeder membawa beban kerja yang lebih berat daripada laki-laki, bertanggung jawab atas peran produksi untuk keluarga, di mana lakilaki hanya memiliki satu peran produksi.

Ekspresi wajah Siti yang tertunduk dan terdiam menunjukkan betapa perempuan pesisir harus menerima semua keadaan hidupnya. Ekspresi ini juga menunjukkan ketidakberdayaan perempuan atas keadaan yang menimpanya. Kesenjangan sosial yang dialami perempuan pesisir, dalam keluarga nelayan menjadi sangat terlihat nyata pada pengadeganan ini. Perempuan pesisir hidup dalam kekurangan dan keterbatasan dalam segala hal. Bahkan dalam hal paling penting yang menyangkut seluruh kesejahteraan keluarga yakni makna fungsional dapur demi memenuhi kebutuhan keluarga.

\section{Membantu Penghasilan Suami di Ruang Publik}

Level denotasi. Siti menjajakan hasil olahan laut berupa peyek, kepada pengunjung Pantai Parangtritis. Level konotasi, membantu penghasilan suami. Selain memegang keuangan keluarga, istri nelayan juga bekerja membantu penghasilan suami memenuhi kebutuhan keluarga. Pada dasarnya keluarga Siti merupakan keluarga yang kurang mampu, sehingga pendapatan dari suami dalam memenuhi kebutuhan harian tidak 
mencukupi. Kondisi ini membuat para perempuan istri nelayan mayoritas menjual ikan dan hasil olahan laut lainnya untuk andil dalam pencapaian kesejahteraan. Boserup (1984) menilai bahwa perbedaan produktivitas antara kerja laki-laki dan perempuan dalam masyarakat primitf tidak terlalu besar, keduanya menghasilkan barang dan jasa untuk keperluan keluarga.

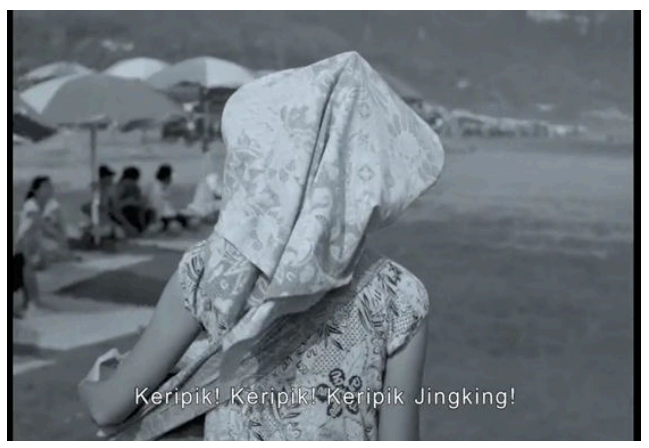

Gambar 3: Siti Berjualan Peyek (menit ke 00:18:47)

Besarnya dominasi perempuan pesisir dalam berbagai aspek, mulai dari wilayah domestik dan wilayah publik menyebabkan perempuan harus bisa mengambil keputusan atas segala masalah dalam kedua wilayah tersebut dengan atau tanpa suaminya. Di samping berbagai pekerjaan tambahan, istri nelayan sebagai ibu rumah tangga tetap melaksanakan pekerjaan rutinnya, mengurus rumah tangga, mengasuh anak, memasak, mencuci dan lain-lain. Pergeseran peran domestik perempuan ke ruang publik tercatat sebagai atribut penting dalam realitas sosial, ekonomi, dan politik (Abdullah, 2003).

\section{Ketidakberdayaan Diri: Ruang Publik yang Terbatas}

Level Denotasi. Siti duduk dan membungkus peyek bersama ibu mertuanya. Mereka tengah membicarakan mengenai pekerjaan seorang Tenaga Kerja Indonesia. Namun Siti terlihat menolak bujukan Darmi untuk pekerjaan seperti itu dengan berbagai alasan, salah satunya mengenai status pendidikannya yang tidak lulus SMA.

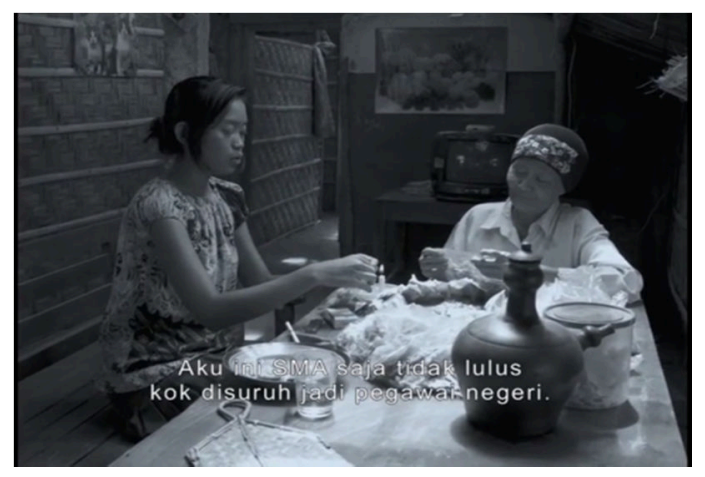

Gambar 4: Darmi Menceritakan Teman-teman Siti yang Menjadi TKW (menit ke 00:14:56)

Level konotasi, ketidakberdayaan diri. Dalam shoot tersebut, sulitnya mencari pekerjaan terlihat jelas dalam dialog yang diucapkan Siti. Pekerjaan sebagai pegawai negeri dan tenaga kerja di luar negeri menjadi pilihan lain bagi perempuan pesisir selain bekerja di rumah menjadi seorang istri nelayan. Sulitnya 
mencari pekerjaan juga dibatasi oleh beberapa faktor yang juga dikemukakan Siti. Pendidikan yang tinggi diperlukan untuk menjadi seorang pegawai negeri, sedangkan Siti bahkan tidak menyelesaikan pendidikannya di jenjang SMA. Kedua, pekerjaan sebagai tenaga kerja di luar negeri yang membutuhkan pelatihan dan uang muka yang tidak sedikit.

Penolakan Siti atas tawaran Darmi terlihat tidak hanya pada keterbatasan pendidikan namun juga kerterbatasan ekonomi. Terlihat kemiskinan menjadi masalah utama keluarga siti, dapat dilihat rumah Siti hanya berdinding anyaman bambu dan beralaskan tanah. Harapan atas penghasilan tinggi dan kehidupan yang lebih baik diuangkapkan juga oleh Darmi dengan menceritakan orang lain dan pekerjaannya, yang diharapkan Siti dapat mengikuti jejak mereka serta mendapatkan kehidupan yang lebih baik. Hal ini didukung dengan dialog Darmi, “Terus, Si Imah, dia kerja di Taiwan jadi TKW. Katanya digaji lima juta". Secara tersirat, merupakan keinginan Darmi untuk menunjukkan jalan keluar kepada Siti agar memiliki penghasilan besar.

Pendidikan bukan menjadi hal utama dalam kehidupan masyarakat pesisir. Banyak masyarakat pesisir baik laki-laki maupun perempuan mengalami putus sekolah akibat keterbatasan ekonomi. Selain itu banyaknya beban dalam keluarga, seperti keterlibatan perempuan dan anak-anak dalam berjalannya perekonomian di daerah pesisir juga menjadi penyebab mereka terpaksa putus sekolah.

Rendahnya tingkat pendidikan di daerah pesisir ini selanjutnya akan menjadi sumber timbulnya permasalahan dalam masyarakat. Seperti ditegaskan Basrowi dan Juariyah (2010) bahwa masyarakat yang memiliki tingkat sosial ekonomi yang rendah cenderung memiliki tingkat pendidikan yang rendah pula. Hal ini selanjutnya akan mempengaruhi tingkat kesejahteraan masyarakat dan memperlambat kemajuan desa pesisir. Keterbatasan tingkat ekonomi juga berpengaruh pada akses pendidikan anakanak desa pesisir.

Tingkat ekonomi yang rendah dan penghasilan yang tidak menentu menyebabkan sulitnya akses untuk mendapatkan pendidikan yang layak. Mahalnya biaya sekolah membuat masyarakat di daerah pesisir tidak dapat melanjutkan pendidikan dan berhenti di tengah jalan. Kurangnya sarana pendidikan yang memadai di wilayah pesisir juga menyumbangkan sulitnya akses pendidikan. Angka putus sekolah yang sangat 
tinggi menyebabkan pola pikir masyarakat pesisir masih sangat terbelakang dan sulit untuk menerima perubahan serta sulit untuk mencari pekerjaan yang layak.

Tingkat pendidikan dan kesejahteraan masyarakat pesisir yang rendah khususnya pada perempuan pesisir membuat berbagai masalah sosial dan ekonomi terus-menerus terjadi. Anggapan bahwa perempuan tidak perlu bersekolah tinggi dan keterbatasan biaya menyebabkan banyak perempuan memiliki tingkat pendidikan yang rendah atau bahkan tidak dapat menyelesaikan pendidikannya.

Kurangnya pengetahuan dan pengalaman perempuan akan mempengaruhi kinerjanya dalam sektor publik. Dengan kekurangan ini banyak perempuan pesisir yang terpaku pada sumber daya laut yang ada dan tidak dikembangkan. Hal ini lah yang membuat usaha perempuan pesisir dalam memenuhi kebutuhan keluarga terhambat. Jika tidak ada variasi dalam pengolahan, maka tidak akan meningkatkan nilai jual sumber daya laut tersebut. Pada akhirnya, konsumen akan bosan dan penjual olahan menjadi berkurang.

\section{SIMPULAN}

Berdasarkan hasil penelitian, peneliti menyimpulkan tiga temuan bagaimana potret perempuan pesisir direpresentasikan. Pertama, mobilitasnya pada ruang domestik. Perempuan pesisir tidak terlepas dari pengabdiannya kepada suami dan keluarga. Kedua, membantu penghasilan suami di ruang publik. Ketiga, ketidakberdayaan diri yang mengakibatkan terbatasnya perolehan pekerjaan di ruang publik. Ketiga temuan ini bukanlah suatu usaha peneliti untuk melakukan generalisasi terhadap potret perempuan pesisir. Sebagai perempuan Jawa, Siti tidak sepenuhnya menerapkan konsep perempuan Jawa dengan berbagai alasan. Namun Siti juga tidak melepaskan konsep perempuan Jawa pada dirinya. Dengan peran ganda yang dimiliki perempuan pesisir akibat desakan ekonomi, pada akhirnya perempuan pesisir tidak dapat melepaskan diri dari tanggung jawab di wilayah domestiknya.

\section{UCAPAN TERIMA KASIH}

Ucapan terimakasih peneliti haturkan kepada Tuhan Yang Maha Esa atas segala berkat dan karunianya, keluarga peneliti yang senantiasa mendukung proses penelitian ini. Terimakasih mendalam peneliti ucapkan juga kepada pihak lain yang telah membantu proses penyelesaian penelitian ini.

\section{DAFTAR PUSTAKA}


Abdullah, I. (2003). Sangkan Paran Gender. Yogyakarta: Pustaka Pelajar.

Balci, V. \& Ozgen, C. What Sprts Advertising Tell to Us? Semiotic Analysis. Journal of Education and Training Studies, 5(6), 24-32. doi: 10.11114 jets.v5i6.2387.

Basrowi \& Juariyah, S. (2010). Analisis Kondisi Sosial Ekonomi dan Tingkat Pendidikan Masyarakat Desa Srigading, Kecamatan Labuhan Maringgai, Kabupaten Lampung Timur. Jurnal Ekonomi Pendidikan, 7(1), 58-81.

Boserup, E. (1984). Peranan Wanita dalam Perkembangan Ekonomi. Yogyakarta: Yayasan Obor Indonesia.

Chandler, D. (2007). Semiotic: The Basics (2th ed.). New York: Routledge.

Elvinaro, Ardianto \& Erdinaya, L. K. (2004). Komunikasi Massa Suatu Pengantar. Bandung: Remaja Rosdakarya.

Boulding, J.R. (ed.), (2016). Elise Boulding: Writings on Feminism, the Family and Quakerism, Pioneers in Arts, Humanities, Science, Engineering, Practice 8. DOI: 10.1007/978-3-319-30978-1

Dzulkarnain, I. (2009). Dinamika Relasi Suami Istri Pada Masyarakat Pesisir Madura (Studi Terhadap Manusia Pasir Di Sumenep). Jurnal Pamator, 2(1).

Fatmasari, D. (2014). Analisis Sosial Ekonomi dan Budaya Masyarakat Pesisir Desa Waruduwur, Kecamatan Mundu, Kabupaten Cirebon. Jurnal Al-Amwal, 6(1), 144 166. doi: 10.24235/amwal.v6i1.255

Kolker, R. P. (2001). Film, Form and Culture. Indianapolis: McGrawHill.
Kusnadi. (2015). Pemberdayaan Perempuan Pesisir. Yogyakarta: Graha Ilmu. Pemberdayaan Perempuan Pesisir Dalam Mengembangkan Mata Pencaharian Alternatif Berbasis Penerapan Teknologi Tepat Guna. Diakses pada 28 Januari 2018, dari http://fib.unej.ac.id/pemberdayaan-perempuan-pesisir/.

Kusumo, Rani Andriani Budi, Anne Charina, Gema Wibawa Mukti. (2013). Analisis Gender Dalam Kehidupan Keluarga Nelayan Di Kecamatan Pangandaran Kabupaten Ciamis. Jurnal Social Economic Of Agriculture, 2(1), 4253.

Prasetyo, Kurniawan Andre. (2017). "Representasi Perempuan Jawa Pesisir dalam Film Siti (Analisis Semiotika Roland Barthes dalam Film Siti)." Skripsi Sarjana, Fakultas Ilmu Sosial Dan Politik, Universitas Muhammadiyah Yogyakarta, Yogyakarta.

Salamah. (2005). Peranan Wanita Dalam Perekonomian Rumah Tangga Nelayan Di Pantai Depok Parangtritis Bantul. Jurnal PKS, 4(14) $73-84$.

Siregar, Ashadi. (2004). Ketidakadilan Konstruksi Perempuan dalam Film dan Televisi. Jurnal Ilmu Sosial dan Ilmu Politik. 7(3), 335350.

Sukri, S. S., \& Sofwan R. (2001). Perempuan dan Seksualitas dalam Tradisi Jawa. Yogyakarta: Kerjasama Pusat Studi Wanita (PSW), IAIN Walisongo dengan Gama Media. 


\title{
BULLYING AND VERBAL-NONVERBAL COMMUNICATION AMONG A GROUP OF COLLEGE STUDENTS
}

\author{
Siti Khadijah \\ Program Studi Ilmu Komunikasi FKSB Universitas Islam 45 \\ kh4d1j4h@gmail.com
}

\begin{abstract}
Bullying is one of problems of Universities in Indonesia. In 2006, there were 29 cases of physical violence, 67 cases of sexual violence, and 96 ases of psychic violence in college. This research aimed to analyse bullying cases among a group of college students from the point of views of verbal and non-verbal communications. Using qualitative method, there were acts of bullying in the form of verbal communication experienced by victims in the form of harsh words that belittle the victim, scolding, screaming, giving negative nickname even a month-monthly friend of a class, and done in front of the crowd. While harassment in the form of nonverbal communication is a cynical view of the perpetrator against the victim, the view of degrading the victim by considering the victim as a "fool", making the distance with the victim by not including victims in the chat group, not invited to take a walk, be kept in class. In addition, the victim also got a kick, spit on, thrown with goods. Negative impacts are anxiety, quarreling with abusers, and declining learning achievement.
\end{abstract}

Keywords: Verbal non-verbal communications, bullying, students

\begin{abstract}
ABSTRAK
Perundungan merupakan salah satu masalah di beberapa universitas di Indonesia. Pada tahun 2006, ada 29 kasus kekerasan fisik terjadi di universitas, 67 kasus kekerasan seksual dan 96 kasus kekerasan psikis. Penelitian ini bertujuan untuk menganalisis kasus perundungan di antara sekelompok mahasiswa dari sudut pandang komunikasi verbal dan nonverbal. Dengan menggunakan metode kualitatif hasil penelitian menunjukkan bahwa tindakan perundungan dalam bentuk komunikasi verbal yang dialami oleh korban berupa kata-kata kasar yang meremehkan korban, cacian, teriakan, memberi julukan negatif bahkan menjadi bulan-bulanan teman satu kelas, dan dilakukan dihadapan orang banyak. Sedangkan perundungan dalam bentuk komunikasi nonverbal berupa pandangan sinis pelaku terhadap korban, pandangan merendahkan korban dengan menganggap korban sebagai "orang bodoh", membuat jarak dengan korban dengan tidak mengikutsertakan korban dalam chat group, tidak diajak berdarmawisata, dijauhkan di kelas. Selain itu korban juga pernah mendapat tendangan, diludahi, dilempar dengan barang. Dampak negatif yang ditimbulkan adalah perasaan cemas, bertengkar dengan pelaku perundungan, dan menurunnya prestasi belajar.
\end{abstract}

Kata-kata Kunci: Komunikasi non verbal -verbal, perundungan, mahasiswa 


\section{PENDAHULUAN}

Aksi perundungan (bullying) dapat berujung pada tindakan kekerasan dalam dunia pendidikan seperti di perguruan tinggi yang marak terjadi di Indonesia. Pemberitaan di salah satu media nasional pada 2014 memuat peristiwa kekerasan di Sekolah Tinggi Ilmu Pelayaran (STIP) yang merenggut nyawa salah seorang mahasiswa bernama Dimas Dikita Handoko (Tanjung, 2014). Peristiwa kekerasan tersebut bukanlah yang pertama kali terjadi. Selain itu, ada peristiwa kekerasan di Institut Pemerintahan Dalam Negeri (IPDN) yang dilakukan oleh senior kepada junior pada 2007 (Yusuf, 2007). Berbagai kasus kekerasan di perguruan tinggi menambah panjang daftar jumlah korban yang berjatuhan di lembaga kependidikan dan hal ini seakan mengindikasikan bahwa dunia pendidikan di Tanah Air telah menebar teror bagi anak didiknya sendiri. Tindakan kekerasan sendiri bisa dikategorikan kepada tindakan perundungan. Tindakan perundungan terhadap sesama, terlebih yang terjadi di lingkungan institusi pendidikan, terutama di ranah pendidikan tinggi seperti universitas menjadi keprihatinan berbagai kalangan.

Tidak hanya di Indonesia, perundungan juga terjadi di negara maju seperti Jepang. Survei yang dilakukan pada 2004 oleh Departemen Pendidikan Jepang menyebutkan bahwa terdapat 24.898 kasus perundungan di perguruan tinggi. Dari jumlah tersebut, 12.307 kasus terjadi di perguruan tinggi swasta (PTS). Pada 2006, di Indonesia terdapat 247 kasus kekerasan fisik (29 kasus terjadi di perguruan tinggi), 426 kasus kekerasan seksual (67 kasus di perguruan tinggi), dan 451 kasus kekerasan psikis (96 kasus di perguruan tinggi) (Simbolon, 2012). Menurut data dari KPAI, saat ini kasus perundungan menduduki peringkat teratas pengaduan masyarakat. Dari 2011 hingga Agustus 2014, KPAI mencatat 369 pengaduan terkait masalah tersebut. Jumlah itu sekitar 25\% dari total pengaduan di bidang pendidikan sebanyak 1.480 kasus. Perundungan yang disebut KPAI sebagai bentuk kekerasan di perguruan tinggi, mengalahkan tawuran pelajar, diskriminasi pendidikan, ataupun pungutan liar (Republika, 15 Oktober 2014)

Data di atas menunjukkan bahwa masalah perundungan merupakan salah satu permasalahan yang penting untuk diperhatikan dalam dunia pendidikan. Wiyani (2012) mengungkapkan bahwa tindakan perundungan cenderung kurang diperhatikan atau diabaikan dalam kehidupan sehari-hari. Masih banyak yang menganggap bahwa perundungan merupakan tindakan yang tidak berbahaya, khususnya di dikalangan mahasiswa perguruan tinggi. Padahal, tindakan perundungan apabila dibiarkan terus-menerus dapat memberikan dampak negatif bagi korbannya dan mengganggu proses pembelajaran (Simbolon, 2012). Dampak yang ditimbulkan dari tindakan perundungan, korban perundungan dapat mengalami gangguan pada fisik maupun psikologisnya.

Menilik poin di atas, penelitian ini bertujuan untuk menganalisis perundungan yang terjadi di Fakultas Komunikasi Universitas Islam 45 Bekasi dari sisi komunikasi verbal dan non- 
verbal serta dampak-dampak yang ditimbulkan oleh perundungan. Berikut adalah perumusan masalah dari penelitian ini:

1. Apa saja bentuk-bentuk komunikasi dan tindakan perundungan di kalangan mahasiswa Fakultas Komunikasi, Sastra, dan Bahasa UNISMA Bekasi?

2. Apa dampak yang ditimbulkan dari tindakan perundungan dikalangan mahasiswa Fakultas Komunikasi, Sastra, dan Bahasa UNISMA Bekasi?

\section{KERANGKA PEMIKIRAN}

\section{Komunikasi verbal dan nonverbal}

Simbol atau pesan verbal adalah semua jenis simbol yang menggunakan satu kata atau lebih. Hampir semua rangsangan wicara yang kita sadari termasuk ke dalam kategori pesan verbal di sengaja, yaitu usaha-usaha yang dilakukan secara sadar untuk berhubungan dengan orang lain secara lisan. Suatu sistem kode verbal disebut bahasa. Bahasa dapat didefinisikan sebagai seperangkat simbol, dengan aturan untuk mengombinasikan simbol-simbol tersebut, yang digunakan dan dipahami suatu komunitas. Bahasa verbal adalah sarana untuk menyatakan pikiran, perasaan, dan maksud kita. Bahasa verbal menggunakan kata-kata yang merepresentasikan berbagai aspek realitas individual kita (Mulyana, 2007).

Komunikasi verbal dapat dibedakan menjadi komunikasi lisan dan komunikasi tulisan. Komunikasi lisan dapat didefinisikan sebagai suatu proses di mana seorang pembicara berinteraksi secara lisan dengan pendengar untuk mempengaruhi tingkah laku penerima. Komunikasi tulisan adalah apabila keputusan yang dituliskan oleh seseorang yang disandikan dalam simbol- simbol yang dituliskan pada kertas atau pada tempat lain yang bisa dibaca, tertulis, yang dapat berupa surat, memo, buku petunjuk, gambar, laporan. Sedangkan lisan dapat berupa percakapan antar pribadi secara tatap muka, atau melalui telpon, radio, televisi, dan lain-lain.

Di lain pihak, pesan nonverbal adalah semua isyarat yang bukan katakata. Menurut Larry A Samovar dan Richard E Porter, komunikasi nonverbal mencakup semua rangsangan (kecuali rangsangan verbal) dalam suatu setting komunikasi, yang dihasilkan oleh individu dan penggunaan lingkungan oleh individu, yang mempunyai nilai pesan potensial bagi pengirim atau penerima. Sehingga dapat disimpulkan bahwa komunikasi nonverbal merupakan merupakan perilaku yang disengaja dan tidak disengaja sebagai bagian dari sebuah peristiwa komunikasi secara keseluruhan dan pengiriman pesan nonverbal kepada orang lain tanpa disadari memiliki makna bagi orang tersebut.

\section{Perundungan}

Righby dalam Anesty (2009) merumuskan perundungan sebagai sebuah hasrat untuk menyakiti yang diperlihatkan dalam aksi sehingga menyebabkan seseorang menderita. Aksi tersebut dilakukan secara langsung oleh seseorang atau sekelompok orang yang lebih kuat dan tidak bertanggung jawab. Tindakan perundungan dilakukan secara berulang-ulang dan dengan perasaan senang (Astuti, 2008: 3). Olweus (1993) 
berargumen bahwa mahasiswa yang menjadi korban perundungan sulit untuk mempertahankan diri. Perundungan merupakan perilaku negatif yang mengakibatkan seseorang dalam keadaan tidak nyaman/terluka dan biasanya terjadi berulang-ulang "repeated during successive encounters".

Terdapat tiga kategori praktik perundungan yaitu: (a) fisik,(b) nonfisik,(c) mental atau psikologis. Contoh perundungan fisik adalah menampar, menimpuk, menjegal, menginjak kaki, meludahi, memalak, melempar dengan barang, dan menghukum. Di lain pihak, perundungan verbal adalah memaki, menjuluki, menghina, meneriaki, mempermalukan di hadapan umum, menuduh, menyoraki, menebar gosip, serta memfitnah. Sedangkan tindakan perundungan mental adalah memandang sinis, memandang penuh ancaman, mempermalukan di hadapan umum, mendiamkan, mengucilkan, mempermalukan, meneror melalui pesan pendek telepon genggam atau email, memelototi, serta mencibir (Sejiwa, 2008).

Perundungan menyebabkan
dampak negatif kepada korban-
korbannya. Carlisle (2007) memaparkan
beberapa dampak perundungan antara
lain perasaan kesepian, rasa malu, rasa
tidak aman, bahkan luka-luka fisik pada
korban perundungan fisik. Selain itu,
Righby (2002) menyatakan dampak
negatif perundungan seperti
kesejahteraan psikologis yang rendah,
menarik diri dari pergaulan dan
cenderung untuk membolos dari
perguruan tinggi, serta tingkat kecemasan

yang sangat tinggi sehingga korban merasa depresi dan memiliki dorongan untuk melakukan tindakan bunuh diri.

\section{Dampak Perundungan}

Tindakan perundungan, merupakan tindak kekerasan yang bisa menimbulkan kerugian pada korban, baik dalam hal fisik maupun psikis. Carlise menguraikan efek pengalaman menjadi korban perundungan yang terjadi pada mahasiswa yaitu:

1. Psikologis, perasaan kesepian, malu, timbul perkara untuk balas dendam, cemas, mudah merasa tertekan, tidak percaya diri, kesulitan membaur dengan kelompok, dan sebagainya.

2. Dampak psikologis juga meliputi rasa takut, rasa tidak aman, dendam, dan menurunya semangat belajar mahasiswa, daya konsentrasi, kreatifitas, hilang inisiatif, daya tahan (mental), menurunya rasa percaya diri, stress, depresi, dan sebagainya. Dan dalam jangka panjang bisa berakibat pada penurunan prestasi dan perubahan perilaku mahasiswa.

3. Fisik, mengakibatkan organ-organ tubuh mahasiswa mengalami kerusakan, seperti memar, luka-luka, dan sebagainya. Secara spesifik, Rigby membagi dampak psikologis korban perundungan menjadi empat kategori, yaitu; (a) memiliki kesejahteraan psikologis yang rendah. pada ketegori ini kesadaran mental korban menjadi lemah, namun kodisi ini tidak terlalu berbahaya. Perasaan tidak bahagia muncul pada diri korban, selain juga perasaan mudah marah, sensitif, 
serta harga dirinya yang rendah, (b) memiliki pandangan dan kemampuan sosial yang rendah. korban yang berada pada kategori ini seringkali menarik diri dari pergaulan, dan sebaliknya lebih suka mengisolasi diri dari dan cenderung untuk membolos perguruan tinggi, (c) psychological distress, pada kategori ini korban memiliki tingkat kecemasan yang sangat tinggi. Korban merasa depresi dan memiliki dorongan untuk melakukan tindakan bunuh diri, (d) dampak negatif secara fisik, misalnya luka-luka akibat serangan fisik, serta penyakit lainnya seperti sakit kepala, deman, flu dan batuk.

\section{METODE PENELITIAN}

Penelitian ini menggunakan metode penelitian kualitatif yang merupakan upaya untuk menghasilkan data deskriptif. Penelitian kualitatif adalah tradisi tertentu dalam ilmu pengetahuan sosial yang secara fundamental tergantung pada pengamatan pada manusia dalam kawasannya sendiri dan berhubungan dengan orang-orang tersebut dalam bahasanya dan dalam peristilahannya (Maleong, 2011). Disamping data sekunder, penelitian kualitatif juga didapat dari sumber yang primer, yaitu data atas informasi yang diperoleh dari suatu wawancara langsung dari sumber informan. Data ini diperoleh melalui wawancara dengan subjek penelitian. Dalam mewawancarai narasumber, seorang peneliti harus objektif dalam melakukan penelitiannya sehingga dalam menganalisis data hasilnya dapat seakurat mungkin.

\section{HASIL DAN PEMBAHASAN}

\section{Tindakan Perundungan}

Berdasarkan wawancara yang dilakukan kepada mahasiswa, khususnya kepada teman-teman pelaku perundungan, perundungan difahami sebagai suatu tindakan kekerasan yang dilakukan oleh pihak yang kuat terhadap pihak yang lemah. Menurut Smith et al. (2003), perundungan adalah suatu aksi negatif yang secara intens bertujuan untuk mengintimidasi serta menyakiti orang lain. Tindakan Perundungan juga selalu dihubungkan dengan tindak kekerasan. Wujud tindakan perundungan terjadi dalam tiga kategori yaitu perundungan fisik, perundungan non fisik, dan perundungan mental (Sejiwa, 2008). Bila dilihat dari tiga kategori perundungan tersebut maka, ketiga kategori perundungan tersebut pernah dialami korban.

a) Perundungan fisik, seperti tindakan menampar, menimpuk, menjegal, menginjak kaki, meludah didepan korban, melempar dengan barang, berkelahi satu lawan satu.

b) Perundungan non fisik, seperti memaki, menjuluki, menghina, meneriaki, mempermalukan di hadapan teman-teman satu kelas, menuduh tanpa alasan yang kuat, menyoraki, menebar gosip, serta memfitnah korban

c) Perundungan mental atau psikologis, seperti memandang dengan sinis, memandang penuh ancaman, mempermalukan di hadapan umum, mendiamkan dengan tidak 
memberitahukan

informasi

mengenai matakuliah apakah mengenai tuga kelompok atau tugas pribadi, mengucilkan dengan tidak mengikutsertakan korban dalam group whatshApp kelas, dan mencibir. Menganggap korban "orang bodoh" dan tidak memiliki kemampuan apa-apa. Namun pandangan berbeda diungkapkan oleh PC, bahwa teman-teman di kelas awalnya tidak memandang bodoh GL, HW, dan IL, korbanlah yang membuat teman-teman dikelas melakukan perundungan kepada korban. Misalnya ketika ada tugas kelompok para korban tidak mau aktif bertanya dan bekerja sama dalam tim. Sehingga para pelaku tindakan perundungan pun menganggap korban tidak mampu mengerjakan tugas kelompok dengan baik dan menggap mereka bodoh dan itu terlihat dari pandangan mata teman-teman.

Tindakan perundungan yang dilakukan tentunya memiliki dampak yang negatif bagi pelaku dan korban perundungan, seperti yang diungkapkan oleh PC, teman sekelas korban :

“...dampaknya tidak adanya lagi kebersamaan atau memiliki sekutu/geng sendiri-sendiri baik dalam kelas maupun diluar kelas. Korban lebih bermain dengan berbeda fakultas atau jurusan dibandingkan jurusannya sendiri (menjauh secara teratur). Korban merasa nyaman dengan yang berbeda jurusan atau fakultas dibandingkan berbincangbincang dengan pelaku perundungan (mahasiswa dari satu jurusan)..."
Pada dasarnya baik pelaku dan korban perundungan menyadari bahwa tindakan perundungan dapat merugikan bagi mereka. Tindakan perundungan sebagai bentuk komunikasi yang menyampaikan pesan kepada korban perundungan bahawa pelaku dianggap sebagai "penindas" superior, dan harus dijauhi. Sementara bagi korban perundungan anggapan kerap muncul dari temanteman satu kelas, seperti, korban kurang bisa membaur diantara teman-teman sekelas, dianggap "bodoh" karena sikap kurang rasa percaya diri yang diperlihatkan oleh korban.

Sementara bagi korban sendiri dampak perundungan berupa; jarang mendapatkan informasi mengenai tugas yang diberikan oleh dosen, rasa sedih, rasa takut, dan rasa kecewa terhadap teman-teman satu angkatan. Penilaian negatif tidak hanya muncul dari temanteman satu angkatan melainkan dari adik angkatan kelas dan dari teman-teman yang berbeda jurusan atau program studi karena korban lebih sering dan nyaman berinteraksi serta berkomunikasi dengan teman-teman yang berbeda fakultas dan jurusan.

\section{Perundungan dalam Bentuk Komunikasi Verbal - Nonverbal}

Hingga saat ini di Universitas Islam ' 45 ' belum ada data statistik yang menginformasikan tentang jumlah tindakan perundungan yang dilakukan oleh mahasiswa kepada mahasiswa lainnya baik oleh senior kepada junior atau sesama teman satu angkatan, seperti yang terjadi pada mahasiswa Program Studi IK dengan inisial HW. Korban 
perundungan HW mengungkapkan bahwa dirinya kerap menjadi bahan ledekan oleh teman-teman satu angkatan, tidak saja dalam bentuk komunikasi verbal dengan penggunaan kata-kata ledekan dan makian. Perundungan dalam bentuk komunikasi verbal berupa penggunaan bahasa lisan berupa katakata, kalimat, dan unsur-unsur bahasa lainya. Menurut Baryadi (2012) bahwa berbahasa adalah bagian dari tingkah laku manusiawi dan dalam tingkah laku itu sangat mungkin orang melakukan sesuatu yang dapat dikategorikan sebagai serangan secara verbal, artinya serangan menggunakan kata-kata (verbal attack) kepada orang lain yang tidak lain merupakan kategori tindakan perundungan. Berikut ungkapan dari HW:

“ ...saya sering mendapat ledekan dari teman-teman saya. Tidak hanya satu orang saja yang meledek saya, lebih dari tiga orang, baik teman-teman yang lakilaki dan juga teman-teman yang perempuan. Biasanya yang meledek orangnya itu-itu aja sih. Padahal saya tidak pernah berbuat yang merugikan mereka. Tapi saya tidak tahu kenapa mereka suka meledek dan menekan saya."

Apa yang diungkapkan oleh HW dibenarkan oleh teman satu angkatan HW yang bernama PC, HW memang kerap mendapatkan tindakan perundungan dalam bentuk komunikasi verbal berupa kata-kata kasar yang meremehkan korban seperti kata "emang loe bisa", "kayak pinter aja", "kemana aja loe?", "masih hidup loe?" bahkan menjadi bulanbulanan, dan itu dilakukan ramai-ramai dengan saling sahut menyahut. Berikut ungkapan dari PC :

"tindakan perundungan juga dilakukan dalam bentuk verbal, yaitu para pelaku perundungan berbicara dengan nada yang tinggi, menunjuk-nujuk korban, mentertawakan korban".

Dampak perundungan secara lisan juga dirasakan korban dalam bentuk nilai yang dikeluarkan oleh dosen. Korban yaitu HW, GL dan IL mendapatkan nilai $\mathrm{D}$ dari dosen karena pelaku perundungan menyampaikan bahwa HW, GL dan IL tidak aktif dalam kegiatan yang ditugaskan oleh dosen bersangkutan. Padahal menurut korban, mereka sudah banyak berkontribusi dalam kegiatan tersebut seperti menjaga properti dengan menginap dilokasi kegiatan. Korban pun merasa kecewa terhadap dosen yang bersangkutan karena mempercayai sepenuhnya apa yang disampaikan oleh YG,ID,S,I,N,R, dan A (pelaku perundungan) tanpa mau mendengarkan apa yang disampaikan oleh HW, GL dan IL.

Tindakan perundungan juga terjadi dalam bentuk komunikasi nonverbal. Komunikasi nonverbal sendiri menurut Ruben dan Stewart (2005) memiliki beberapa saluran yaitu paralanguage, wajah dan gerakan tubuh (kinesics), sentuhan (haptics), penampilan fisik serta proximity (jarak) dan chonemics (waktu). Tindakan perundungan dalamb entuk komunikasi nonverbal yaitu dengan memperlihatkan pandangan mata yang menganggap korban "orang bodoh" dan tidak memiliki kemampuan apa-apa. Namun anggapan "orang bodoh" yang diperlihatkan oleh teman-teman dikelas bukan tanpa alasan. Menurut PC bahwa 
teman-teman awalnya tidak memandang bodoh GL, HW, dan IL, Korbanlah yang membuat teman-teman dikelas menilai korban sebagai "orang bodoh". Misalnya ketika ada tugas kelompok para korban tidak mau aktif bertanya dan bekerja sama dalam kelompok. Sehingga para pelaku tindakan perundungan pun menganggap korban tidak mampu mengerjakan tugas kelompok dengan baik dan menggap mereka bodoh dan itu terlihat dari pandangan mata temanteman.

"Pengakuan dalam kerja tim : temanteman selalu menganggap remeh hasil kerja dari korban, sehingga terkadang dalam tugas kelompok korban justru tidak diberi tugas. Informasi mengenai tugas, para korban sering terkadang tidak mendapat informasi mengenai tugas, sehingga mereka sering terlambat mengumpulkan tugas".

Perlakuan lain dari perundungan nonverbal dengan menunjuk-nujuk korban, mentertawakan korban. Selain itu juga GL, HW, dan IL mendapat pengucilan dari pelaku perundungan dengan tidak memasukan korban ke dalam group chat whatsApp sehingga ketika ada informasi dari dosen dan petugas administrasi Fakultas, para pelaku perundungan sering kali tidak memberitahukannya kepada korban. Menurut korban ada dua group chat yang dibentuk oleh teman-temannya yaitu group WA dan BBM, namun tidak satupun mereka diikutsertakan ke dalam group chat tersebut. Padahal group tersebut berisi informasi mengenai tugas, jadwal kuliah, perpindahan waktu atau jam matakuliah dan pengumuman lainnya. HW, GL dan IL pernah tidak diberitahu mengenai tugas matakuliah Pendidikan Kewarganegaraan, sehingga komponen nilai tugas menjadi 0 (nol) dan mereka tidak lulus matakuliah Pendidikan Kewarganegaraan. Selain tidak dimasukkan ke group, korban juga di asingkan di kelas. Bentuk pengasingan ini masuk ke dalam bentuk komunikasi nonverbal dalam hal membuat jarak (proximity). Padahal GL sudah berusaha mendekatkan diri dan bergabung dengan teman-teman dikelas dengan duduk satu baris ketika kuliah, namun biasanya teman-teman langsung pergi mencari tempat duduk yang lain.

Bentuk lain dari proximity juga terlihat dengan mengucilkan korban. Korban tidak dilibatkan dalam kegiatan pergi bareng oleh teman-teman seangkatan korban, misalnya ke Puncak, nonton bareng. Korban perundungan biasanya tahu teman-teman pergi ke Puncak, nonton film dari foto-foto di Facebook (FB).

Perundungan non verbal tidak hanya merugikan secara mental atau psikologi tapi juga secara materi. Pelaku perundungan pernah menendang telpon genggam milik IL. GL mengungkapkan bahwa pernah suatu kali pada saat perkuliahan berlangsung di kelas, telpon genggam IL ditendang. oleh NS, apakah itu sengaja atau tidak, saya tidak tahu, dan saya benar-benar marah. Selain itu menurut GL, HW juga pernah di dorong oleh ID di kelas.

Berbeda dengan HW, FS yang diduga korban perundungan dari Program Studi SI memiliki sedikit cerita yang berbeda. FD diperlakukan oleh teman sengkatannya berbeda dengan HW, GL, dan IL dari program studi IK. FD 
merupakan mahasiswa pindahan dari universitas lain dan sejak bergabungnya FD ke program studi SI, FD dinilai berperilaku aneh oleh teman-temannya di dalam kelas. Hal ini diungkapkan oleh BQ, teman FD yang menyatakan bahwa perilaku dari FD dianggap aneh dan memiliki pendapat yang berbeda dari kebanyakan teman-temannya di kelas. Selain itu FD juga jarang bergabung dengan teman-temannya di kelas. Setiap sehabis matakuliah usai, FD biasanya langsung pulang atau entah kemana. Berbeda dengan teman-teman sekelasnya yang lebih memilih untuk tidak langsung pulang melainkan mengobrol terlebih dahulu atau kumpul bareng. Perilaku FD ini yang membuat teman-teman satu kelasnya cenderung mengucilkan FD dan setiap kali FD mengungkapkan pendapatnya dikelas, teman-teman FD akan mengarahkan pandangan ke FD dengan mimik wajah yang memperlihatkan keanehan dengan argumen yang disampaikan oleh FD.

Perilaku FD juga mendapat perhatian dari dosen mata kuliah yang mengajar di kelas FD. Bapak RB mengungkapkan pendapatnya tentang FD bahwa:

" Secara akademik sih FD biasa saja, bahkan cenderung tidak terlalu bagus. FD cenderung kurang bergabung dengan teman-temannya. Bahkan temantemannya juga menganggap aneh FD, karena punya pandangan yang berbeda jika ditanya tentang sesuatu hal ketika di kelas."

Sebenarnya tindakan pelaku perundungan kepada korban pada awalnya tidak sengaja dilakukan dan tidak benar-benar berniat dilakukan, karena pada awal perkuliahan yakni pada semester pertama pelaku dan korban perundungan sering kali melakukan komunikasi secara lisan dengan meledek atau bahkan bercanda dengan bahasa yang kasar. Namun tindakan perundungan ini justru terus berlanjut karena korban yang justru membuka peluang yang membuat pelaku semakin meledek bahkan mengucilkan korban. Contoh ketika ada tugas kelompok para korban tidak mau aktif bertanya dan bekerja sama dalam tim. Sehingga para pelaku pun makin mengucilkan korban dan menganggap korban tidak mampu mengerjakan tugas kelompok dengan baik. Ditambah lagi korban perundungan tidak berusaha untuk melawan pelaku perundungan atau diam saja dengan tindakan perundungan yang dilakukan oleh pelaku sehingga pelaku semakin gencar dan tampak menikmati tindakan perundungan tersebut seperti yang diungkapkan oleh PC:

"Ketika korban datang, salah satu pelaku mulai meledeknya kemudian temanteman pelaku yang lain pun ikut-ikutan meledek. A: 'kemana aja lo?', B: 'masih hidup lo?'."

Umumnya pelaku perundungan berjenis kelamin laki-laki. Hal ini senada dengan hasil survei yang dilakukan oleh Latitude News pada 40 negara. Salah satu faktanya adalah bahwa pelaku perundungan biasanya para mahasiswa laki-laki. Sedangkan mahasiswi lebih banyak melakukan tindakan perundungan dalam bentuk komunikasi verbal seperti menggosip ketimbang melakukan tindakan perundungan dalam bentuk komunikasi nonverbal seperti 
menendang, memukul dan lain sebagainya (Pratiwi, 2014).

Atas dasar atau alasan apapun, tindakan perundungan tidak dapat dibenarkan, karena apabila dibiarkan berlangsung terus menerus, efek perundungan bagi kedua belah pihak baik bagi korban maupun pelaku tindakan perundungan akan mengganggu proses belajar mengajar. Menurut Suryabrata dalam Wiyani (2012) pada usia 18 tahun sampai 25 tahun disebut sebagai usia mahasiswa sebenarnya. Pada usia tersebut mahasiswa digolongkan dalam masa dewasa awal. Mahasiswa merupakan peserta didik yang sedang mengikuti proses belajar mengajar di perguruan tinggi. Rentang usianya berkisar antara 18-19 tahun sampai 24-25 tahun. Jadi berdasarkan usia, mahasiswa sudah masuk pada masa dewasa awal. Hal ini berarti bahwa pada usia itu seseorang sudah dianggap dewasa dan selanjutnya dianggap sudah mempunyai tanggungjawab terhadap perbuatanperbuatannya, yakni sudah dapat dikenai sangsi-sangsi pidana tertentu apabila melanggar peraturan hukum.

\section{Dampak Perundungan}

Hasil penelitian yang dilakukan di asrama Universitas A (Simbolon 2012), perundungan mengakibatkan korbannya menjadi putus asa, menyendiri, tidak mau bergaul, tidak bersemangat, bahkan berhalusinasi. Meskipun ejekan, cemoohan, olok-olok mungkin terkesan sepele dan terlihat wajar, namun pada kenyataannya, hal itu tidak sepenuhnya benar. Hal-hal tersebut dapat menjadi senjata tak kenal ampun yang secara perlahan namun pasti dapat menghancurkan seseorang. Aksi-aksi negatif dari tindakan perundungan dapat mengancam segala aspek kehidupan para korbannya. Apalagi jika tindakan perundungan mengarah pada aksi kekerasan fisik. Berikut adalah dampakdampak perundungan yang dianalisis dalam penelitian ini:

1. Perasaan cemas dirasakan oleh korban-korban seperti FL, HW, dan IL. Perasaan itu muncul pada saat mereka harus presentasi tugas di depan temantemannya. Seketika akan muncul kegugupan dan mudah merasa tertekan, dan tidak percaya diri terhadap hasil yang sudah dilakukan oleh korban. Korban juga merasa sulit untuk membaur dengan teman-teman seangkatannya atau temanteman lainnya. Seperti yang terjadi pada HW. HW merasa kesulitan memulai pertemanan dalam dunia nyata, tidak merasa percaya diri, dan sebagainya. Namun HW menjadi orang yang berbeda ketika berhadapan dengan dunia virtual, HW punya banyak teman. Dampak psikologis juga meliputi rasa takut, rasa tidak aman, dendam, dan menurunnya semangat belajar mahasiswa, daya konsentrasi, kreativitas, hilang inisiatif, daya tahan (mental), menurunnya rasa percaya diri, stres, depresi, dan sebagainya. Dalam jangka panjang, bisa berakibat pada penurunan prestasi dan perubahan perilaku mahasiswa. Hal ini dirasakan oleh GL yang sempat depresi dan malas datang ke kampus karena merasa dikucilkan oleh teman-temannya dan pernah berniat untuk pindah ke kampus lain.

"Efeknya dari perlakuan teman-teman ke saya, bikin saya males ke kampus, dan 
bikin saya mau pindah ke kampus lain. Karena segala tugas saya tidak dapet informasi dari teman-teman, saya dikucilkan. Sampai beberapa matakuliah saya tertinggal dan tidak lulus."

Dari prestasi yang didapatkan oleh korban perundungan menurut dosen pembimbing akademik HW, Kartini Rosmalah DK, hasilnya tidaklah bagus. Karena memang dari hasil evaluasi kehadiran HW, beliau sering tidak hadir, bahkan tidak aktif selama kurang lebih satu semester. Akibatnya, HW banyak tertinggal matakuliah dibandingkan dengan teman-temannya. Begitu juga dengan GL dan IL, walaupun prestasi GL dan IL tidak seburuk HW, karena kedua korban sudah mampu menyelesaikan kuliahnya. Berdasarkan hasil wawancara dengan GL, GL cenderung gagap hingga berkeringat jika mengalami tekanan.

2. Fisik, mengakibatkan organorgan tubuh mahasiswa mengalami kerusakan, seperti memar, luka-luka, dan sebagainya. Berdasarkan hasil wawancara dengan GL dan HW, korban pernah mengalami luka fisik karena adu fisik dengan para pelaku perundungan.

Penanganan perundungan yang dapat dilakukan oleh perguruan tinggi sebagai institusi pendidikan melalui kebijakan perguruan tinggi dengan cara membuat seperangkat peraturan tentang pencegahan, penghentian serta intervensi bagi korban maupun pelaku. Kebijakan lainnya adalah menerapkan serta menegakkan kerjasama, tanggung jawab seluruh sivitas akademika kampus (Milsom \& Gallo, 2006). Kebijakan yang dapat mengantisipasi tindakan perundungan antara lain melalui peningkatan pemahaman agama, diantaranya melalui penanaman karakter islami sebagai visi dari Universitas Islam'45' Bekasi, menghidupkan ajaran agama,serta menegakkan nilai-nilai etika di kampus kepada seluruh sivitas akademika.

Menurut Milsom dan Gallo (2006), kampus harus menciptakan aktivitas serta atmosfer untuk memunculkan kreativitas dan menciptakan rasa nyaman bagi mahasiswa. Aktivitas mahasiswa seperti kegiatan ekstrakurikuler menjadi pilihan yang dianggap paling tepat untuk penanganan tindakan perundungan. Selain itu, kegiatan yang telah menjadi program wajib di UNISMA seperti penanaman karakter islami melalui kegiatan BTQ (Baca Tulis Alquran), mentoring dirasakan cukup efektif untuk mencegah tindakan perundungan kepada sesama mahasiswa. Kebijakan antisipasi terhadap tindakan perundungan yang dilakukan oleh mahasiswa diharapkan mendapat dukungan oleh berbagai pihak di universitas. Upaya pencegahan perundungan memang harus menjadi perhatian semua pihak. Seluruh komponen yang terkait dengan lingkungan kampus antara lain mahasiswa, dosen, maupun orangtua harus punya peran untuk menghentikan perundungan.

\section{SIMPULAN}

Berdasarkan wawancara yang dilakukan kepada mahasiswa, khususnya kepada teman-teman pelaku perundungan, perundungan difahami sebagai suatu tindakan kekerasan yang dilakukan oleh pihak yang kuat terhadap pihak yang lemah. Tindakan Perundungan juga 
selalu dihubungkan dengan tindak kekerasan. Wujud tindakan perundungan yang dialami oleh mahasiswa berupa (a) perundungan fisik, seperti tindakan menampar, menimpuk, menjegal, menginjak kaki, meludah didepan korban, melempar dengan barang, berkelahi satu lawan satu; (b) perundungan non fisik, seperti memaki, menjuluki, menghina, meneriaki, mempermalukan di hadapan temanteman satu kelas, menuduh tanpa alasan yang kuat, menyoraki, menebar gosip, serta memfitnah korban; (c) perundungan mental atau psikologis, seperti memandang dengan sinis, memandang penuh ancaman, mempermalukan di hadapan umum, dan membuat jarak.

Perundungan dalam bentuk komunikasi verbal yang dialami oleh korban berupa penggunaan berupa kata-kata kasar yang meremehkan korban seperti kata "emang loe bisa", "kayak pinter aja", "kemana aja loe?", “masih hidup loe?” bahkan menjadi bulan-bulanan, dan itu dilakukan ramai-ramai dengan saling sahut menyahut. Sedangkan perundungan dalam bentuk komunikasi nonverbal berupa pandangan sinis pelaku terhadap korban, pandangan merendahkan korban dengan menganggap korban sebagai "orang bodoh", membuat jarak dengan korban dengan tidak mengikutsertakan korban dalam chat group, tidak diajak berdarmawisata, dijauhkan di kelas. Selain itu korban juga pernah mendapat tendangan, diludahi, dilempar dengan barang.

Tindakan perundungan tentu akan berdampak bagi pelaku maupun korban. Tindakan perundungan sebagai bentuk komunikasi menyampaikan pesan negatif kepada korban perundungan bahawa pelaku dianggap sebagai "penindas" superior, dan harus dijauhi. Sementara bagi korban perundungan anggapan kerap muncul dari temanteman satu kelas, seperti, korban kurang bisa membaur diantara teman-teman sekelas, dianggap "bodoh" karena sikap kurang rasa percaya diri yang diperlihatkan oleh korban. Universitas sebagai institusi pendidikan harus menciptakan kebijakan-kebijakan yang dapat mengantisipasi, menghentikan tindakan perundungan, dengan cara peningkatan pemahaman agama, diantaranya melalui penanaman karakter islami sebagai visi dari Universitas, menghidupkan ajaran agama,serta menegakkan nilai-nilai etika di kampus kepada seluruh sivitas akademika.

\section{UCAPAN TERIMA KASIH}

Terimakasih yang mendalam peneliti ucapkan kepada Universitas Islam 45 Bekasi yang mendukung peneliti dalam kegiatan penelitian. Ucapan terima kasih peneliti haturkan pula pada mahasiswa Fakultas Komunikasi, Sastra, dan Bahasa Universitas Islam 45 Bekasi yang telah bersedia menjadi informan dalam penelitian ini. Terima kasih pada pihak lain yang selama ini telah membantu proses penyelesaian penelitian ini.

\section{DAFTAR PUSTAKA}

Baryadi. Praptomo I. 2012. Bahasa, Kekuasaan, dan Kekerasan. Universitas Sanata Darma: Yogyakarta

Bungin, B. 2011. Konstruksi Sosial Media Massa. Kencana Prenada: Jakarta. 
Carlisle, N. 2007. School Bullying: Do

Adults Survivors Perceive Long Term Effects of Traumatology. Edisi November 2007.

Christin. 2009. Dampak psikologis bullying pada siswa SMA. Gunadarma University: Yogyakarta.

Control, D. 2013. Bullying and Suicide: A Public Health Approach. Journal of Adolesent Health.

Devito J.A. 2010. Komunikasi Antar Manusia. Edisi Kelima. Profesional Books: Jakarta .

Donegan, R. 2012. Bullying and Cyberbullying: History, Statistics, Law, Prevention and Analysis.The Elon Journal of Undergraduate Research in Communications. Vol. 3 No. 1: 33-42.

Effendy, O. U. 2003. Ilmu, Teori dan Filsafat Komunikasi. Citra Aditya Bakti: Bandung.

Harper, D. Online Etymology Dictionary [internet]. Tersedia dari http://www.etymonline.com/index.php?a llowed_in_frame $=0 \&$ search $=$ bully\&sear chmode $=$ none.

Kamus Besar Bahasa Indonesia. Tindak [internet]. Tersedia dari http:// (http://kbbi.web.id/intimidasi).

Kriyantono, R. 2006. Teknis Praktis Riset Komunikasi. Media Kencana Prenada: Jakarta.

Lewis, Philip V. 1987. Organizational Communication : The Essence of Effective Management. John Willey \& Sons: New York.
Maleong, LJ. 2009. Metodologi Penelitian Kualitatif. Remaja Rosdakarya: Bandung.

Mantra B.I. 2000. Demografi Umum. Pustaka Pelajar: Yogyakarta.

Muhammad, A. 2005. Komunikasi Organisasi. Jakarta: Bumi Aksara.

Mulyana, D. 2005. Ilmu Komunikasi Sutu Pengantar. Bandung: Remaja Rosda Karya.

Neuman WL. 2003. Social Research Methods: Qualitative and Quantitative Approaches. 5th Ed. Pearson Education Inc: Boston.

Olweus, D. 1978. A useful evaluation design and effects of the Olweus bullying prevention program. Psychology, Crime and La. Guilford Publications: New York.

Olweus, D. Peer harassment: a critical analysis and some important issues [internet]. Tersedia dari http://www.olweus.org/public/bullying.p age.

Olweus D. 1993. Bullying at School: What We Know and What We Can Do. Blackwell: Cambridge, MA.

Pratiwi, A. Kasus Bullying di Indonesia [internet]. Tersedia dari https://teen.kapanlagi.com/girls/pubertas /kasus-bullying-di-indonesia261e53.html.

Purwata H. 2014. Mahasiswanya Tewas, UIN Suka Yogya Kutuk Aksi Serangan!. Republika : Jakarta.

Rakhmat, Jalaluddin. 2005. Psikologi Komunikasi (Edisi Revisi). PT Remaja Rosdakarya: Bandung. 
Righby, K. 2002. New Perspective On Bullying. Jessica: London.

Riauskina, I, Djuwita, R, Soesetia, S.R. 2005. Gencet-Gencetan" di mata siswa/siswi kelas 1 SMA: Naskah Kognitif tentang arti scenario, dan dampak "Gencet-Gencetan". Jurnal Psikologi Sosial. Vol. 12 No. 1: 1-13.

Ruben, Brent D, Stewart, Lea P. 2005. Communications and Human Behaviour. Alyn and Bacon; USA

SEJIWA (Yayasan Semai Jiwa Amini) (2008). Mengatasi kekerasan dari sekolah dan lingkungan anak. Grasindo: Jakarta.

Simbolon, M. 2012. Perilaku Bullying pada Mahasiswa Berasrama. Jurnal Psikologi. Vol. 39 No.2: 1-20.
Susanto, S. Astrid. 1977. Komunikasi dalam Teori dan Praktek. Bandung: Bina Cipta.

Tanjung A. Langkah Tegas STIP Marinda Pasca Kematian Dimas Dikita Handoko [internet]. Tersedia dari http://www.merdeka.com/peristiwa/lang kah-tegas-stip-marunda-pasca-kematiandimas-dikita-handoko.htmlAgib Tanjung | Selasa, 29 April 2014 05:05

Wiyani, N. A. 2012. Save our children from school bullying. AR-RUZZ Media: Yogyakarta.

Yusuf I. 2007. Arogansi dan Kekerasan di IPDN. Kompas: Jakarta. 